\title{
Some characteristics of sperm motility in European hake (Merluccius merluccius, L., 1758)
}

\author{
A.-L. Groison ${ }^{1,2,{ }^{*}}$, C. Fauvel ${ }^{3}$, M. Suquet ${ }^{4}$, O. S. Kjesbu ${ }^{2}$, J. R. Le Coz $^{5}$, Mayer $^{1,6}$, J. Cosson $^{7}$ \\ ${ }^{1}$ Department of Biology, University of Bergen, Bergen, Norway \\ ${ }^{2}$ Institute of Marine Research, Bergen, Norway \\ ${ }^{3}$ Ifremer, Station Expérimentale d'Aquaculture, Palavas les Flots, France \\ ${ }^{4}$ Ifremer, PFOM/ARN, Argenton, France \\ ${ }^{5}$ Ifremer, PFOM/LPI, Plouzané, France \\ ${ }^{6}$ Norwegian School of Veterinary Science, Oslo, Norway \\ ${ }^{7}$ UMR 7009, CNRS, Université P. \& M. Curie, Marine Station, Cedex, France \\ *: Corresponding author : A.-L. Groison, email address : Anne-Laure.Groison@imr.no
}

\begin{abstract}
:
The objective of this paper is to characterize some of the sperm motility parameters in European hake (Merluccius merluccius), which is considered to be a species with aquaculture potential. The total ATP, $\mathrm{ADP}$ and AMP concentrations were determined using high-performance liquid chromatography on hake sperm samples collected during the winter-early spring in the Bay of Biscay (France) $(n=22)$ and on hake sperm samples collected during the summer-early autumn in waters off Western Norway $(n=5)$. The Adenylate Energy Charge (AEC) was deduced from these data. Computer Assisted Sperm Analysis (CASA) was used to measure a series of parameters characterizing the motility and the sperm swimming performances. Changes in salinity of the swimming medium affected all the measured motility parameters. The sperm velocity and the straightness of the movement were at maximum when sperm was activated with $100 \%$ filtrated sea water (100 SW) but decreased sharply later. When sperm was activated in filtrated sea water ( $50 \%$ diluted with distilled water: $50 \mathrm{SW}$ ) the values of these parameters increased (with a lower percentage of active cells) during the first $2.5 \mathrm{~min}$ and thereafter decreased slowly. In $50 \mathrm{SW}$, the initial velocity was lowered but the swimming period lasting 4.5 times longer than in $100 \mathrm{SW}$ (but with a lower percentage of actively swimming cells). Initial sperm motility (percentage of swimming cells) in $100 \mathrm{SW}$ was affected by sperm storage duration. Undiluted sperm could be stored at $4^{\circ} \mathrm{C}$ for 5 days and still show $13 \pm 7 \%$ motility; the velocity and straightness of the movement were at maximum at the earliest period of measurement (0.5-1 day of storage) and then decreased gradually to reach their minima after 4 days of storage. Further, both the AEC and ATP content decreased with storage time, with the AEC decreasing from $0.78 \pm 0.07$ (mean \pm SD) at stripping time to $0.20 \pm 0.09$ after 2 days of storage. Over the same period ATP content decreased from $85 \pm 80$ to $5 \pm 4$ nanomoles $10^{-9}$ spermatozoa, these data presenting a high variability.
\end{abstract}




\section{Introduction}

Successful broodstock management of any aquaculture species relies on the availability of good quality gametes. Knowledge on the sperm biology of a species is important for two main reasons. Firstly, for fertilization under captive conditions (sperm quality varies between individuals and over the spawning period). Secondly, for the development of short- and long-term sperm storage, including cryopreservation. Longterm storage is clearly beneficial for broodstock management, when viable sperm has to be used out-of-season, but also potentially useful for conservation purposes (cryopreserved sperm). Percent motility and sperm velocity have been correlated to reproductive success in fish (Lahnsteiner and Patzner, 1998; Rurangwa et al., 2004). For the analysis of these indicators of sperm quality, computer-assisted sperm analysis (CASA) represents a most objective and comprehensive method of quantification (Wilson-Leedy and Ingermann, 2007). CASA has therefore been employed in the determination of individual variation of sperm quality (Lahnsteiner and Patzner, 1998). The chemical characteristics of the motility-inducing medium essentially determine the duration of sperm motility even though other factors play a role, such as energy level (Cosson, 2004). Sperm motility parameters depend mainly on the endogenous ATP stores accumulated during fish spermatogenesis (Perchec et al., 1995). Elucidating the effect of the salinity on sperm motility and investigating the effects of sperm storage duration on adenylate compounds content are therefore of importance in gaining an understanding of the mechanisms underlying potential reproductive success in oviparous fishes (Wilson-Leedy et al., 2009).

Merluccius merluccius has seen considerable interest as potential aquaculture species. Understanding the biology of this species and more specifically of its reproductive biology including its sperm biology is therefore of increasing interest.

In the Bay of Biscay, hake spawn from January to May with a defined spawning peak between February and March (Lucio et al, 2000; Alvarez et al., 2004). Casey and Pereiro (1995) showed that the peak of spawning time of hake occurs later as the latitude increases; Kvenseth et al. (1996) recorded ripening hake in August in Norwegian waters.

To date, very little is known about hake sperm biology. By the lateral insertion of the flagellum and the location of the centrioles outside the nuclear fossa, hake sperm belongs to the perciform type (Medina et al., 2003). Cosson (2004) and Cosson et al. (2008a, 2008b) analyzed morphological changes of the flagella in the cod (Gadus morhua) and hake spermatozoa using high resolution video microscopy and stroboscopic flash illumination. The paper of Groison et al. (2008) contains information on some hake sperm characteristics such as the volume and concentration and its storage capacity.

The aim of this investigation was to characterise hake sperm motility parameters using CASA sperm tracker technology by examining (i) fresh hake sperm swimming characteristics, (ii) the effect of the salinity on movement characteristics and (iii) the reliance of the sperm energetic content on its motility characteristics.

\section{Materials and methods}

\section{Fish collection and sperm extraction}

Sperm of 27 wild European hake were sampled during the natural spawning season. A total of 5 sexually mature males were sampled from mid-August until mid-October 2006 in offshore Western Norway $\left(61^{\circ} 34^{\prime} \mathrm{N}, 5^{\circ} 56^{\prime} \mathrm{W}\right)(\mathrm{Nw})$ and 22 sexually mature males 
were sampled between 8 and 11 March 2007 in offshore areas of the Bay of Biscay, France $\left(47^{\circ} 44^{\prime} \mathrm{N}, 4^{\circ} 2^{\prime} \mathrm{W}\right)(\mathrm{Fr})$. Whenever possible, the following fish characteristics were recorded: total length $(T L$ in $\mathrm{cm}$ ), total weight ( $T W$ in $\mathrm{g})$, condition factor $(K=[$ Total weight $\left.\left./(\mathrm{TL})^{3}\right]^{\star} 100\right)$, gonadosomatic index (GSI $=[100 \times$ Gonad weight $/ \mathrm{TW}]$ in \%), and hepatosomatic index (HSI $=$ [Liver weight $/ \mathrm{TW}]{ }^{* 100}$ in \%). The sperm was manually stripped after careful rinsing of the fish genital pore. Sperm was collected directly into graduated syringes. Special care was taken not to contaminate the milt sample with blood, urine, faeces or sea water. Any potentially contaminated milt samples (as judged by visual inspection) were discarded. Syringes were stored in individual labeled sealed plastic bags to avoid cross-contamination, and stored on crushed ice. All sperm manipulations were performed at $4^{\circ} \mathrm{C}$.

\section{Sperm preparation and activation}

In order to ensure a synchronous activation of all test spermatozoa, a two-step dilution procedure was used (Billard and Cosson, 1992). A non-activating medium (NAM) initially designed for seabass (Dicentrarchus labrax) sperm by Fauvel et al. (1998) was employed for hake sperm. Three microliters of sperm were first transferred to $45 \mu \mathrm{L}$ of $\mathrm{NAM}$, then, spermatozoa were activated by adding $3 \mu \mathrm{L}$ of this sperm suspension to $45 \mu \mathrm{L}$ from one of the two activating medium (AM) tested: either $100 \%$ filtrated sea water (100SW) or $50 \%$ filtrated sea water diluted in distilled water (50SW). The osmolalities of these two test AMs were measured by osmometry (Osmomat ${ }^{\circledR}$ 030-M, $\mathrm{GMBH}$, Gonotec, Berlin) to 1000 and $500 \mathrm{mOsmol.L}^{-1}$, respectively. Bovine Serum Albumin (BSA $0.1 \%$ ) was added to both NAM and AM to prevent sperm sticking. Due to the mixing period, observation and recording of motility could start only within a 15 seconds lag period after sperm activation. Each sperm sample was monitored and recorded on VHS video tape by the same experimenter using a CCD B/W video camera model (Sony XC-ST50 CE) attached to a CH30 Olympus camera with a negativecontrast objective lens (magnification: $x$ 200). The percentage of motile cells was estimated every $15 \mathrm{~s}$ after activation with two to three replicates of sperm until all spermatozoa ceased any activity. Vibrating or stationary sperm cells (non progressive) were considered as non-motile. Room temperature was set at $22^{\circ} \mathrm{C}$ and samples were kept on crushed ice.

\section{Sperm storage at $4^{\circ} \mathrm{C}$}

The effect of storage at $4^{\circ} \mathrm{C}$ on swimming performances was tested on sperm samples by measuring the percentage of motility every $24 \mathrm{~h}$ after stripping for several days (called "X"). The sperm storage period was calculated as the time between the time of stripping and the time at which the motility was recorded. The different storage duration classes were defined as day $\mathrm{X} \pm 12 \mathrm{~h}$. When storage period ranged 0 to $12 \mathrm{~h}$ the class was named 0.5 .

\section{Swimming sperm characteristics: computer assisted sperm analysis (CASA)}

The sperm motility parameters were evaluated using video records from all the 5 Norwegian sperm samples. The records of sperm movements were further analyzed in details at Ifremer Palavas, France, using CASA on Hobson Sperm Tracker (Hobson Tracking Systems Ltd, Sheffield, U.K. version SPR72VET). Software settings of the 
CASA programme were optimized for adaptation to the tracking of hake sperm: search radius $=4.13 \mu \mathrm{m} ;$ aspect $=1.49 ;$ refresh time $=1 \mathrm{~s} ;$ thresholds $=+40 /-128 ;$ filter weightings $1=1,2=4,3=2,4=1$; image capture rate $=25$ frames. $s^{-1}$, minimum track time $=0.4 \mathrm{~s}$; immotile process $=$ off. The Hobson sperm tracker did not consider immotile spermatozoa in the calculation of the different motility parameters. When the value of the percentage of motility was zero, a low velocity was however recorded due to the heads drift of spermatozoa presenting immotile flagella.

Video recordings of spermatozoa activated in 100 SW were analyzed every $30 \mathrm{~s}$ for a $15 \mathrm{~s}$ duration each time until the end of the sequence; i.e. cessation of any sperm movement. When sperm was activated in $50 \mathrm{SW}$ videotapes were taken and analyzed every $120 \mathrm{~s}$ for the same duration. The Hobson sperm tracker simultaneously generated many movement parameters among which several were previously selected as defined in Table 1. Changes in the sperm motility parameters as a function of the time period elapsed since activation (post activation = p.a.) were plotted for sperm activated by the two AMs (100 SW or $50 \mathrm{SW}$ ).

When sperm was stored at $4^{\circ} \mathrm{C}$ for short periods (less than $32 \mathrm{~h}$ corresponding to storage classes named 0.5 and 1 ), sperm motility parameters were not affected significantly by the different storage times (ANOVA, $p>0.05$ ) which were estimated after sperm activation in $100 \mathrm{SW}$. Therefore, these data were pooled. To study the different motility parameters measured versus sperm storage at $4^{\circ} \mathrm{C}$, only initial data recorded at $15 \mathrm{~s}$ p.a. were included.

\section{Determination of energetics (ATP, ADP, AMP)}

The determination of adenylate compounds content was evaluated using all the 27 sperm samples. Subsamples of unactivated sperm were mixed with $8 \%$ trichloroacetic acid and centrifuged (3000 rpm for $10 \mathrm{~min}$ at $0^{\circ} \mathrm{C}$ ) for removal of the cell debris. The supernatant, containing adenosine 5'-triphosphate (ATP), was neutralized by addition of an alkaline solution. Total ATP, ADP and AMP concentrations were measured using high-performance liquid chromatography (HPLC). The adenylate energy charge (AEC) was defined as (ATP + 1/2 ADP) / (ATP + ADP + AMP) (Atkinson and Walton, 1967). Determinations were performed on total sperm (spermatozoa in seminal fluid). Sperm samples were collected and fixed (in $8 \%$ trichloroacetic) every $24 \mathrm{~h}$ in order to determine the energy content degradation with the storage duration at $4^{\circ} \mathrm{C}$. In addition, sperm from two samples were fixed immediately after stripping.

\section{Statistical analysis}

Results were presented as mean values \pm SD. For motility parameters measurements, samples with an initial percentage of fresh sperm motility lower than $25 \%$ were rejected, considered as bad quality or contaminated sperm samples. All statistical analysis was obtained from use of SigmaStat 3.1. Pearson's correlations were established between the percentage of sperm motility and the CASA motility parameters for each of the two AMs.

\section{Results}

Fish characteristics and sperm production indexes 
Fish characteristics as well as sperm production indexes are presented for the fish and sperm samples used for the CASA study and for determinations of adenylate compounds content (Table 2). When the groups from the two different geographical areas (Nw and $\mathrm{Fr}$ data) showed a statistically significant difference (Student t-test or Mann-Whitney Rank Sum test; $\mathrm{P}<0.05)$, the data were analysed separately. Otherwise, data from both groups were pooled. GSI and HSI were calculated for the Nw data. Similar tests were conducted to investigate the possible effects of fish and sperm collection dates on the Nw sperm motility parameters as well as on the Nw energy content data. Because Fr hake sperm samples were collected over a restricted period of time; no effect of the fish / sperm collection date was considered. No statistically significant difference was found between Nw fish caught in August / September or in October $(P>0.05)$. Furthermore, no male effect was detected for the different sperm motility parameters measured (ANOVA; $P>0.05$ ). Therefore all these data could be pulled together for analysis.

\section{Swimming sperm characteristics and the influence of salinity}

\section{The function of time after post activation}

Spermatozoa activated in $100 \mathrm{SW}$ and $50 \mathrm{SW}$ exhibit different motility characteristics versus time period after activation (Fig. 1). Activation resulting from transfer into 100 SW led to a synchronous response of all activated sperm cells. The percentage of motility was highest at the initial time of measurement $(75 \pm 16 \% ; n=5)$ and was followed by a fall with time p.a. until $7 \mathrm{~min}$ where no progressive movement was detected (Fig. 1a). Conversely, at transfer into $50 \mathrm{SW}$, only part of the spermatozoa population was initially activated $(20 \pm 9 \% ; n=5)$, while maximum motility $(41 \pm 14 \%)$ was observed at approximately $2.5 \mathrm{~min}$ until $5 \mathrm{~min}$ post-activation. A decrease of the percentage of motile cells was further observed until 32 min (mean value), a time's point where no more cells remained motile (Fig. 1a).

When sperm were activated in $100 \mathrm{SW}$ the initial velocity and straightness of the movement were highest at the first time of determination but were decreasing afterwards (Fig. 1 b,c,d,h). When $50 \mathrm{SW}$ was used for activation, the initial velocity increased progressively for the first $2.5 \mathrm{~min}$, then leveled off until about 5 min postactivation while slowly decreasing thereafter (Fig. 1 b,c,d). The initial velocity value was lower compared to that of sperm activated in $100 \mathrm{SW}$, (Fig. 1 b,c,d) but the swimming period lasted 4.5 times longer (Student t-test, $P<0.001$ ) (Fig. 1a). The initial sperm velocity increase and the lowering of the velocities at $50 \mathrm{SW}$ were accompanied by a quite stable straightness of tracks until about $10 \mathrm{~min}$ post-activation and decreased slowly thereafter (Fig. 1h). The mean angular head displacement $\left(D_{\mathrm{MA}}\right)$ and the amplitude of lateral head displacement $\left(A_{\mathrm{LH}}\right)$ increased constantly from activation time until the period where no more cells were motile at $50 \mathrm{SW}$ (Fig. 1 e,g) (NB: low increase regarding $\left.A_{\mathrm{LH}}\right)$. The beat-cross frequency $\left(F_{\mathrm{BC}}\right)$ increased from activation to about 5 min when $50 \mathrm{SW}$ was used and then remained almost constant until about 10 min and then decreased until the end of the motility period at $32 \mathrm{~min}$ (Fig. 1f).

Significant statistical correlations were detected between the different expressions of velocity $\left(V_{\mathrm{SL}}, V_{\mathrm{CL}}, V_{\mathrm{AP}}\right), D_{\mathrm{MA}}, F_{\mathrm{BC}}, S_{\mathrm{TR}}$ and percentage of motile sperm measured in both AM, $100 \mathrm{SW}$ and $50 \mathrm{SW}$ (Table 3). No significant correlation was observed between $A_{\mathrm{LH}}$ and the other parameters. 


\section{Function of storage time at $4^{\circ} \mathrm{C}$}

During the storage period at $4^{\circ} \mathrm{C}$, the percentage of motile sperm in $100 \mathrm{SW}$, decreased from $92 \pm 2 \%$ ( 0.5 day of storage) to $13 \pm 7 \%$ (5 days of storage:) (Fig. 2a); $V_{S L}$ also declined from $47 \pm 5 \mu \mathrm{m} . \mathrm{s}^{-1}$ to $20 \pm 9 \mu \mathrm{m} . \mathrm{s}^{-1}$ (Fig. 2b) and $V_{\text {AP }}$ from $61 \pm 12 \mu \mathrm{m} . \mathrm{s}^{-1}$ to $29 \pm 8 \mu \mathrm{m} . \mathrm{s}^{-1}$ (Fig. 2d), while $S_{\mathrm{TR}}$ decreased from $75 \pm 8 \%$ to $54 \pm 5 \%$ (Fig. $2 \mathrm{~h}$ ). The $F_{\mathrm{BC}}$ and $A_{\mathrm{LH}}$ decreased from first measurement (day 0.5) until fifth day of storage (Fig. 2 $\mathrm{f}, \mathrm{g}$ ). The $D_{\mathrm{MA}}$ showed an opposite trend: an increase from initial values until five days of storage is observed (Fig. 2e).

\section{Determination of energetics (ATP, ADP, AMP)}

The Adenylate Energy Charge (AEC) as well as the ATP and ADP content of sperm decreased with time of storage (Fig. 3a,b). Right after stripping (first time of measurement), the mean AEC was $0.78 \pm 0.07$. A high individual variability in the mean AEC content was observed at 0.5 , one and three days of storage at $4^{\circ} \mathrm{C}$ (Fig. 3a). ATP and ADP concentrations, expressed in nanomoles. $10^{-9}$ spermatozoa, decreased respectively over the first two days period from $85 \pm 80$ to $5 \pm 4$ and from $25 \pm 22$ to $2 \pm 0.5$ (Fig. 3b). Over the same time period, AMP concentrations went from $10 \pm 8$ to $25 \pm 20$ (Fig. 3b). A high variability was also observed of the values determined for ATP, ADP and AMP content.

\section{Discussion}

\section{Motion parameters}

In the present study $V_{\mathrm{SL}}, V_{\mathrm{CL}}, V_{\mathrm{AP}}, D_{\mathrm{MA}}, F_{\mathrm{BC}}$, and $S_{\mathrm{TR}}$ were all significantly correlated with sperm motility assessed as the percentage of motile cells; therefore these motility parameters represent good candidates to objectively describe the sperm motility characteristics in hake. Marine spermatozoa are very 'fast' swimmers (Cosson et al. (2008a). Cosson et al. (2008b) and Groison et al. (2008) reported an initial hake sperm velocity of forward displacement of $130 \mu \mathrm{m} . \mathrm{s}^{-1}$. However, swimming velocity in these previous studies was calculated on the basis of total distance travelled divided by the time taken to travel this distance. Using CASA, a methodology similar to that used in our study, Tuset et al. (2008) showed that the sperm swimming velocity varies among cod males with a maximum $V_{C L}$ of 151.5 to $201.5 \mu \mathrm{m} . \mathrm{s}^{-1}$; in hake our results showed that the maximum $V_{C L}$ varies from 69 to $102 \mu \mathrm{m} . \mathrm{s}^{-1}$. Babiak et al. (2006) found for halibut (Hippoglossus hippoglossus) sperm that initial $V_{\mathrm{CL}}$ and $V_{\mathrm{SL}}$ were 145 and $110 \mu \mathrm{m} . \mathrm{s}^{-1}$ respectively. Thus, our results for hake are on the low side; initial $V_{\mathrm{CL}}, V_{\mathrm{AP}}$ and $V_{S L}$ of 82,64 and $51 \mu \mathrm{m} . \mathrm{s}^{-1}$. The flagellum length in cod is longer $(79 \mu \mathrm{m}$; Tuset et al., 2008) compared to the one of hake (30 $\mu \mathrm{m}$; Medina et al., 2003) suggesting a greater effective ATP mole fraction available for enabling the spermatozoon to swim toward the egg than do spermatozoa with a short flagellum (Vladic et al., 2002).

Hake spermatozoa have a limited efficient progressive period of about $100 \mathrm{~s}$ (Cosson et al., 2008b, 2008c; Groison et al., 2008). Our results show an initial percentage of motility and $V_{\mathrm{AP}}$ respectively decreasing from $75 \%$ and $64 \mu \mathrm{m} . \mathrm{s}^{-1}$ to $34 \%$ and $24 \mu \mathrm{m} . \mathrm{s}^{-1}$ after about $100 \mathrm{~s}$ when activated in $100 \mathrm{SW}$. $S_{\mathrm{TR}}$ and $A_{\mathrm{LH}}$ reached their minimum values as well after $100 \mathrm{~s}$. Taken together, this study therefore is in line with previously 
published observations showing that the efficient progressive period of hake spermatozoa is limited to about $100 \mathrm{~s}$.

The $D_{\mathrm{MA}}$ was inversely related to sperm motility percentage meaning that the sperm trajectories describe circles of smaller and smaller diameter. Thus, high-motility spermatozoa corresponding to the earliest period swim straighter than low-motility spermatozoa (the later period). Our findings corroborated those of Cosson et al. (2008b) who described some aspects of hake sperm flagellar movement: the diameter of the sperm trajectories abruptly decreases and leads to circling of spermatozoa becoming tighter while progressing in the motility period which consequently restricts the efficient progressiveness of sperm cells. The rigidification process following the decrease of the wave amplitude along flagellum observed for turbot (Scophthalmus maximus) spermatozoa by Chauvaud et al. (1995) has been hypothetically related to the cell energy level and its distribution along the flagellum during the motility period: while spermatozoa are progressing in the motility period, the ATP level becomes lower than initially, while that of ADP becomes higher as a consequence of ATP hydrolysis during the motility period. In addition the ATP concentration would decrease faster in the distal part of the flagellum, relatively to the proximal part, which is closer to the ATP source, (i.e. the mitochondria). To study the evolution of the energetic content in hake sperm along its period of motility will be of interest in future studies.

\section{Effect of the salinity of the activating medium}

Sperm motility is initiated in seawater fishes which have adopted external fertilization when sperm are released into seawater. Activation of hake sperm at low salinity AM appears to lengthen its motility period. A trade-off between the mean sperm velocity and duration of sperm movement was emphasized by Burness et al. (2004). In our study, the longer swimming duration in $50 \mathrm{SW}$ may be due to a lower energetic expense due to the lower velocity observed, and consequently energy availability would last longer. Alternatively this could be due to a partial and progressive activation of spermatozoa with differential sensitivity thresholds to osmolality shock, i.e., the motile cells observed as swimmers long after transfer in $50 \mathrm{SW}$ would probably be cells that were not activated at time zero. Since the percent motile sperm and the velocity correlated with fertility (Rurangwa et al., 2004), an environment of lowered osmolality (e.g. in the presence of saline or ovarian fluid while gametes are released) is likely to impact fertility as discussed by Wilson-Leedy et al. (2009). Low salinity results in reduced activity of sperm and low fertilization rates in the Baltic Sea cod (Westin and Nissling, 1991; Nissling and Westin, 1997). Generally, fertilization levels for this gadoid may be influenced by annual variation in the salinity of deep basin spawning areas (Litvak and Trippel, 1998; MacKenzie et al., 1996). Fertilization rates and recruitment processes in hake may be influenced with a limited quantity of sperm for the same reasons.

\section{Effect of storage duration at $4^{\circ} \mathrm{C}$}

Sperm motility performances are very variable after four days storage at $4^{\circ} \mathrm{C}$, ranging from 0 to $75 \%$ (Groison et al, 2008). In the present study, the storage potentiality of hake sperm at $4^{\circ} \mathrm{C}$ was five days resulting in a percentage of motile cells of $13 \pm 7 \%$. Nevertheless, the AEC decreased abruptly, from $0.78 \pm 0.07$ (right after sperm collection) down to $0.20 \pm 0.09$ (after two days of storage). The same was true for the 
ATP content (from $85 \pm 80$ to $5 \pm 4$ nanomoles. $10^{-9}$ spermatozoa over the same time period). ATP, ADP and AMP contents being highly variable, AEC was therefore also clearly fluctuating $[A E C=(A T P+1 / 2 A D P) /(A T P+A D P+A M P)]$. ATP provides the energy for spermatozoa movement (Inaba et al., 1999; Cosson, 2004). This abrupt ATP content decrease was reflected in the percentage of motile spermatozoa which was more than halfed in two days period. Testing fertilization capacity of stored sperm requires the availability of hake broodstock. Maintaining adult hake in captivity however remains difficult (Bjelland and Skiftesvik, 2006).

\section{Conclusion}

An activating medium of reduced salinity affected negatively several hake sperm motility parameters, as measured by CASA, but the spermatozoa's swimming duration time increased. The efficiency of sperm forward movement decreased in full seawater $(100 \mathrm{SW})$ to a large extent with time longer than $100 \mathrm{~s}$ post activation. In addition, during the storage at $4^{\circ} \mathrm{C}$, the percentages of sperm motility as well as the motility parameters declined and this was probably due to the corresponding decrease in the energetic content of the sperm.

\section{Acknowledgements}

The authors thank fishermen and the technical assistance in collecting data at sea, Frank Midtøy and Julie Skadal. Thanks to J.M. Bouquet from the Sars (International Centre for Marine Molecular Biology, Thormøhlensgate 55, N-5008 Bergen, Norway) for technical help and providing us access to laboratory facilities. This study was funded by grant from AURORA project $\mathrm{n}^{\circ} 102000$.

\section{References}

Alvarez, P.; Fives, J.; Motos, L.; Santos, M., 2004: Distribution and abundance of European hake Merluccius merluccius (L.), eggs and larvae in the North East Atlantic waters in 1995 and 1998 in relation to hydrographic conditions. J. Plank. Res. 26, 811826.

Atkinson, D.E.; Walton, G.M., 1967: Adenosine triphosphate conservation in metabolic regulation. Rat liver citrate cleavage enzyme. J. Biol. Chem. 242, 3239-3241.

Babiak, I.; Ottesen, O.; Rudolfsen, G.; Johnsen, S., 2006: Quantitative characteristics of Atlantic halibut, Hippoglossus hippoglossus L., semen throughout the reproductive season. Theriogenol. 65, 1587-1604.

Billard, R.; Cosson, M. P., 1992: Some problems related to the assessment of sperm motility in fresh-water fish. J. Exp. Zool. 261(2), 122-131.

Bjelland, R.M.; Skiftesvik, A.B., 2006. Larval development in European hake (Merluccius merluccius L.) reared in a semi-intensive culture system. Aquaculture Research, 37, 1117-1129.

Burness, G.; Schulte-Hostedde, A.I.; Casselman, S.J.; Moyes, C.D.; Montgomerie, R., 2004: Sperm swimming speed and energetic vary with sperm competition risk in bluegill (Lepomis macorchirus). Behav. Ecol. Sociobiol. 56, 65-70.

Casey, J.; Pereiro, J.A., 1995: European hake (M. merluccius) in the North-east Atlantic. In: Hake: fisheries and markets. Alheit J. \& Pitcher T.J. (Eds.). Chapman \& Hall, London, pp. 125-147. 
Chauvaud, L.; Cosson, J.; Suquet, M.; Billard, R., 1995: Sperm motility in turbot, Scophthalmus maximus, initiation of movement and changes with time of swimming characteristics. Env. Biol. Fish. 43, 341-349.

Cosson, J., 2004: The ionic and osmotic factors controlling motility of fish spermatozoa Aquaculture International 12, 69-85.

Cosson, J.; Groison, A.L.; Suquet, M.; Fauvel, C.; Dreanno, C.; Billard, R., 2008a: Marine fish spermatozoa: racing ephermal swimmers. Reproduction 136, 277-294.

Cosson, J.; Groison, A.L.; Suquet, M.; Fauvel, C., 2008b: Motility characteristics of spermatozoa in cod (Gadus morhua) and hake (Merluccius merluccius). Cybium 32(2) suppl., 176-177.

Cosson, J.; Groison, A.L.; Suquet, M.; Fauvel, C.; Dreanno, C.; Billard, R., 2008c: Studying sperm motility in marine fish: an overview on the state of the art. J. Appl. Ichtyol. 24, 460-486.

Fauvel, C.; Suquet, M.; Dreanno, C.; Zonno, V.; Menu, B., 1998: Cryopreservation of sea bass (Dicentrarchus labrax) spermatozoa in experimental and production simulating conditions. Aquat. Living Resour. 11(6), 387-394.

Groison, A.L.; Suquet, M.; Cosson, J.; Le Coz, J.R.; Jolivet, A.; Garren, F., 2008: Biological characteristics of European hake (Merluccius merluccius) sperm. Cybium 32(2), 178.

Inaba, K.; Kagami, O.; Ogawa, K., 1999: Tctex2-Related Outer Arm Dynein Light Chain Is Phosphorylated at Activation of Sperm Motility. Biochem. Biophys. Res. Commun. 256(1), 177-183.

Kvenseth, P.G.; Skiftesvik, A.B.; Slinde, E., 1996: Hake-next to be farmed. In: Proceedings of the 1996 CalCOFI Symposium, Monterrey, CA.

Lahnsteiner, F.; Patzner, R., 1998: Sperm motility in the marine teleosts Boops boops, Diplodus sargus, Mullus barbutus and Trachurus mediterraneus. J. Fish. Biol. 52, 726742.

Litvak, M.; Trippel, E., 1998: Sperm motility patterns of Atlantic cod (Gadus morhua) in relation to salinity: effects of ovarian fluid and egg presence. Can. J. Fish. Aquat. Sci. 55(8), 1871-1877.

Lucio, P.; Murua, H.; Santurtún, M., 2000: Growth and reproduction of hake (Merluccius merluccius) in the Bay of Biscay during the period 1996-1997. Ozeanografika, 3, 325354.

MacKenzie, B.; John, M.S.; Wieland, K., 1996: Eastern Baltic cod: Perspectives from existing data on processes affecting growth and survival of eggs and larvae. Mar. Ecol. -Prog. Ser. 134(1-3), 265-281.

Medina, A.; Megina, C.; Abascal, F.J.; Calzada, A., 2003: The sperm ultrastructure of Merluccius merluccius (Teleostei, Gadiformes): phylogenetic considerations. Acta Zoologica 84(2), 131-137.

Nissling, A.; Westin, L., 1997: Salinity requirements for successful spawning of Baltic and Belt Sea cod and the potential for cod stock interactions in the Baltic Sea. Mar. Ecol. Prog. Ser. 110, 67-74.

Perchec, G.; Jeulin, C.; Cosson, J.; Andre, F.; Billard, R., 1995: Relationship between sperm ATP and motility of carp spermatozoa. J. Cell Sci. 108, 747-753.

Rurangwa, E.; Kime, D.E.; Ollevier, F.; Nash, J.P., 2004: The measurement of sperm motility and factors affecting sperm quality in cultured fish. Aquaculture 234, 1-28.

Tuset, V.M.; Trippel, E.A.; de Monserrat J., 2008: Sperm morphology and its influence on swimming speed in Atlantic cod. J.Appl. Ichthyol. 24, 398-405.

Vladic, T.V.; Afzelius, B.A.; Bronnikov G.E., 2002: Sperm quality as reflected through morphology in salmon alternative life histories. Biol. Reprod. 66, 98-105. 
Westin, L., and Nissling, A., 1991. Effects of salinity on spermatozoa motility, percentage of fertilized eggs and egg development of Baltic cod (Gadus morhua), and implications for cod stock fluctuations in the Baltic. Mar. Biol. 108:5-9.

Wilson-Leedy, J.G.;Ingermann, R.L., 2007: Development of a novel CASA system based on open source software for characterization of zebrafish sperm motility parameters. Theriogenology 67, 661-672.

Wilson-Leedy, J.G.; Kanuga, M.K.; Ingermann, R.L., 2009: Influence of osmolality and ions on the activation and characteristics of zebrafish sperm motility. Theriogenology 71, 1054-1062.

\section{Tables and Figures}

Table 1.

Table 1. Abbreviations and corresponding definitions

The different hake sperm motility parameters fincluding abbreviations and units (column named "Abb.")\} acquired for using CASA system and the selected data among those generated by the Hobson sperm tracker.

\begin{tabular}{|c|c|c|}
\hline Term & Abb. & Definition \\
\hline Curvilinear velocity & $\begin{array}{l}V_{\mathrm{CL}} \\
\text { in } \mu \mathrm{m} \cdot \mathrm{s}^{-1}\end{array}$ & $\begin{array}{l}\text { Velocity over the actual sperm track, which } \\
\text { included all deviations of sperm head movement }\end{array}$ \\
\hline Average path velocity & $\begin{array}{l}V_{\mathrm{AP}} \\
\text { in } \mu \mathrm{m} \cdot \mathrm{s}^{-1}\end{array}$ & Velocity over a calculated smoothed path \\
\hline Straight line velocity & $\begin{array}{l}V_{S L} \\
\text { in } \mu m \cdot s^{-1}\end{array}$ & $\begin{array}{l}\text { Straight line distance between the start and end } \\
\text { points of the track divided by the time taken for the } \\
\text { sperm to cover the track }\end{array}$ \\
\hline Straightness & $\begin{array}{l}S_{\mathrm{TR}} \\
\text { in \% }\end{array}$ & $\begin{array}{l}\text { Straightness of the movement determined by } \\
\text { dividing } V_{\mathrm{SL}} \text { by } V_{\mathrm{AP}}\end{array}$ \\
\hline $\begin{array}{l}\text { Mean angular } \\
\text { displacement }\end{array}$ & $\begin{array}{l}D_{\mathrm{MA}} \\
\text { in }\end{array}$ & $\begin{array}{l}\text { Measure of the deviation of the sperm path from } \\
\text { linearity }\end{array}$ \\
\hline Beat-cross frequency & $\begin{array}{l}F_{\mathrm{BC}} \\
\text { in } \mathrm{Hz}\end{array}$ & $\begin{array}{l}\text { Frequency with which the sperm crosses the } \\
\text { smoothed path }\end{array}$ \\
\hline $\begin{array}{l}\text { Amplitude of lateral } \\
\text { head displacement }\end{array}$ & $\begin{array}{l}A_{\mathrm{LH}} \\
\text { in } \mu \mathrm{m}\end{array}$ & $\begin{array}{l}\text { Average deviation from the smoothed path based } \\
\text { on the difference in linearity between the } \\
\text { smoothed and sampled paths }\end{array}$ \\
\hline
\end{tabular}


Table 2.

Table 2. Fish characteristics and sperm production values for hake and sperm samples used in this CASA study ( $n=5 \mathrm{Nw}$ samples) and in this study for determinations of adenylate compounds content ( $\mathrm{n}=5 \mathrm{Nw}+22 \mathrm{Fr}$ samples)

For determinations of adenylate compounds content Norwegian (Nw) and French (Fr) samples showed a statistically significant difference in total length (TL), total weight (TW), condition factor (K) and sperm density; therefore, separated mean values \pm SD were calculated for these characteristics. The level of significance is indicated as one, two or three stars corresponding to $\mathrm{P}<0.05, \mathrm{P}<0.01, \mathrm{P}<0.001$ respectively. Oppositely, Nw and Fr data could be pulled for mean values calculations concerning the following characteristics: sperm volume, spermatocrit and total number of spermatozoa. 


\begin{tabular}{|c|c|c|c|c|c|}
\hline Variables & Origin & Mean & S.D. & $N$ & Significance \\
\hline \multicolumn{6}{|l|}{ CASA STUDY } \\
\hline \multicolumn{6}{|l|}{ Fish characteristics } \\
\hline$\underline{T L}(\mathrm{~cm})$ & Nw & 66.4 & 6.3 & 5 & \\
\hline $\mathrm{TW}(\mathrm{g})$ & Nw & 2521.7 & 351.6 & 3 & \\
\hline$\underline{\mathrm{K}}$ & Nw & 0.73 & 0.08 & 3 & \\
\hline GSI (\%) & Nw & 3.74 & 1.90 & 3 & \\
\hline HSI (\%) & Nw & 2.73 & 1.23 & 3 & \\
\hline \multicolumn{6}{|c|}{ Sperm production indexes } \\
\hline Sperm volume (mL) & Nw & 3.4 & 4.8 & 5 & \\
\hline \multicolumn{5}{|l|}{$\left(.10^{-9} \mathrm{sp} \cdot \mathrm{mL}^{-1}\right)$} & \\
\hline Spermatocrit (\%) & Nw & 80.20 & 3.35 & 5 & \\
\hline$\frac{\text { Tot. number of sp. }}{\left(.10^{-9} \mathrm{sp} .\right)}$ & Nw & 23.53 & 29.99 & 5 & \\
\hline \multicolumn{6}{|c|}{ DETERMINATIONS OF ADENYLATE CONTENT STUDY } \\
\hline \multicolumn{6}{|c|}{ Fish characteristics } \\
\hline \multirow[t]{2}{*}{$\underline{\mathrm{TL}(\mathrm{cm})}$} & Nw & 66.4 & 6.3 & 5 & $\star \star \star *$ \\
\hline & $\mathrm{Fr}$ & 38.8 & 8.8 & 22 & \\
\hline \multirow[t]{2}{*}{$\underline{\mathrm{TW}}(\mathrm{g})$} & Nw & 2521. & 351.6 & 3 & ** \\
\hline & $\mathrm{Fr}$ & 445.2 & 262.8 & 21 & \\
\hline \multirow[t]{2}{*}{$\underline{\mathrm{K}}$} & Nw & 0.73 & 0.08 & 3 & * \\
\hline & $\mathrm{Fr}$ & 0.63 & 0.07 & 21 & \\
\hline GSI (\%) & Nw & 3.73 & 1.90 & 3 & \\
\hline HSI (\%) & Nw & 2.73 & 1.23 & 3 & \\
\hline \multicolumn{6}{|c|}{ Sperm production indexes } \\
\hline Sperm volume (mL) & $\mathrm{Nw}+\mathrm{Fr}$ & 2.2 & 2.5 & $27(5 \mathrm{Nw}+22 \mathrm{Fr})$ & \\
\hline Sperm density & Nw & 6.55 & 3.24 & 5 & $\star \star *$ \\
\hline$\left(.10^{-9} \mathrm{sp} \cdot \mathrm{mL}^{-1}\right)$ & $\mathrm{Fr}$ & 15.90 & 4.20 & 21 & \\
\hline Spermatocrit (\%) & $\mathrm{Nw}+\mathrm{Fr}$ & 81.47 & 9.60 & $24(5 \mathrm{Nw}+19 \mathrm{Fr})$ & \\
\hline$\frac{\text { Tot. number of } \mathrm{sp} .}{\left(.10^{-9} \mathrm{sp} .\right)}$ & $\mathrm{Nw}+\mathrm{Fr}$ & 31.45 & 31.14 & $25(5 \mathrm{Nw}+21 \mathrm{Fr})$ & \\
\hline
\end{tabular}


Table 3.

Table 3. Pearson correlations between the different motility parameters and the percentage of hake sperm motility (\% Mot.) when sperm was activated with $100 \mathrm{SW}$ or $50 \mathrm{SW}$

The level of significance is indicated with one, two or three stars corresponding to $\mathrm{P}<0.05, \mathrm{P}<0.01, \mathrm{P}<0.001$ respectively.

\begin{tabular}{lllc}
\hline Correlation established between & \multicolumn{2}{c}{ Pearson's $\boldsymbol{r}$ value } & Significance \\
variable X and \% Mot. & $\mathbf{1 0 0} \mathbf{~ S W}$ & $\mathbf{5 0 ~} \mathbf{~ W}$ & \\
\hline$V_{\mathrm{SL}} / \%$ Mot & 0.936 & 0.977 & $\star \star \star$ \\
$V_{\mathrm{CL}} / \%$ Mot & 0.909 & 0.814 & $\star \star \star$ \\
$V_{\mathrm{AP}} / \%$ Mot & 0.920 & 0.970 & $\star \star \star$ \\
$D_{\mathrm{MA}} / \%$ Mot & -0.979 & -0.851 & $\star \star \star$ \\
$F_{\mathrm{BC}} / \%$ Mot & 0.909 & 0.925 & $\star \star \star$ \\
$S_{\mathrm{TR}} / \%$ Mot & 0.890 & 0.916 & $\star \star \star$
\end{tabular}



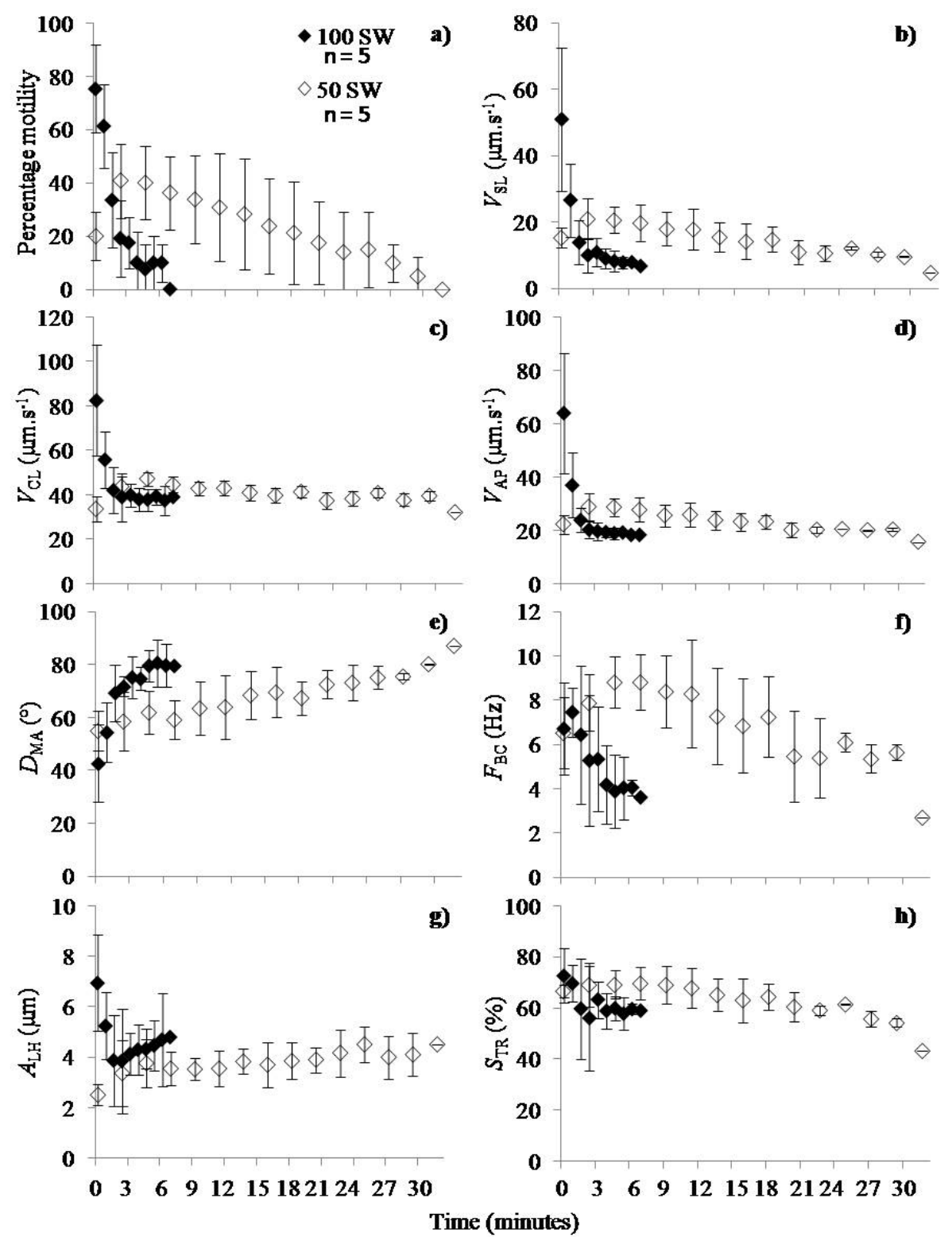

Fig. 1.

Fig. 1. Relationship between salinity and hake sperm motility parameters in relation to time post activation: (a) Percentage of motility (\%Mot.), (b) straight line velocity $\left(V_{\mathrm{SL}}\right)$, (c) curvilinear velocity $\left(V_{\mathrm{CL}}\right)$, (d) average path velocity $\left(V_{\mathrm{AP}}\right)$, (e) mean angular displacement $\left(D_{\mathrm{MA}}\right)$, (f) beat-cross frequency $\left(F_{\mathrm{BC}}\right),(\mathrm{g})$ amplitude of lateral head displacement $\left(A_{\mathrm{LH}}\right)$, (h) straightness $\left(S_{\mathrm{TR}}\right)$ provided by the CASA. Activation in AM was either in $100 \%$ Sea Water (100 SW) (black diamonds) or in $50 \%$ SW diluted by distilled water (50 SW) (open diamonds). Hake sperm stored for 0.5 and one day at $4^{\circ} \mathrm{C}$ were used in this set of measurements. Data represent mean values and standard deviations. 


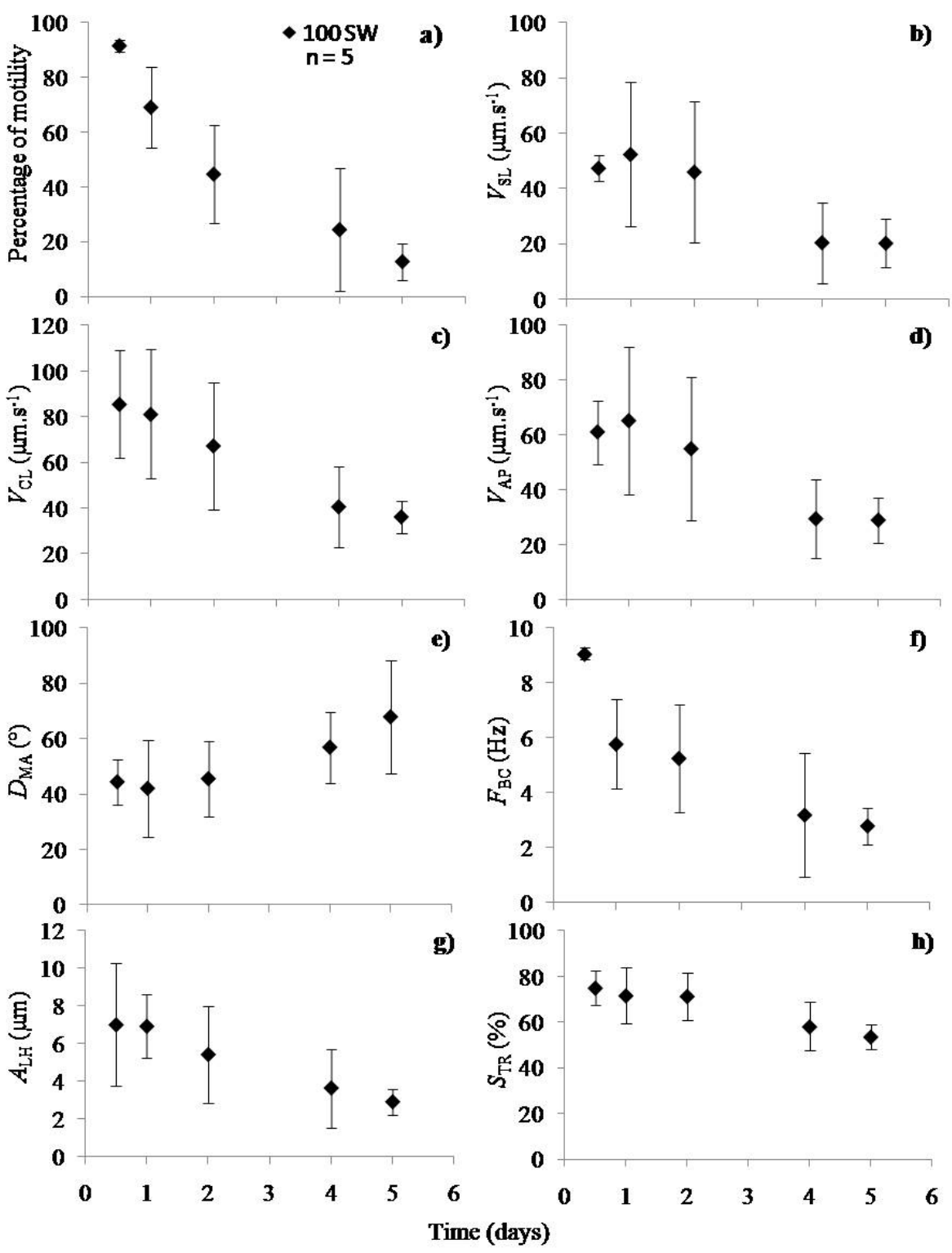

Fig. 2.

Fig. 2. Effect of the duration hake sperm storage on initial motility performances of potent sperm characterized by the following parameters: (a) Percentage of motile cells (\%Mot.), (b) straight line velocity $\left(V_{\mathrm{SL}}\right)$, (c) curvilinear velocity $\left(V_{\mathrm{CL}}\right)$, (d) average path velocity $\left(V_{\mathrm{AP}}\right),(\mathrm{e})$ mean angular displacement $\left(D_{\mathrm{MA}}\right)$, $(\mathrm{f})$ beat-cross frequency $\left(F_{\mathrm{BC}}\right),(\mathrm{g})$ amplitude of lateral head displacement $\left(A_{\mathrm{LH}}\right)$, $(\mathrm{h})$ straightness $\left(S_{\mathrm{TR}}\right)$. All parameters are plotted as a function of storage duration at $4^{\circ} \mathrm{C}$ (in days). Presented data correspond to hake sperm motility at $15 \mathrm{~s}$ post activation when sperm was activated in $100 \%$ Sea Water (100 SW). Data represent mean values and standard deviations. 

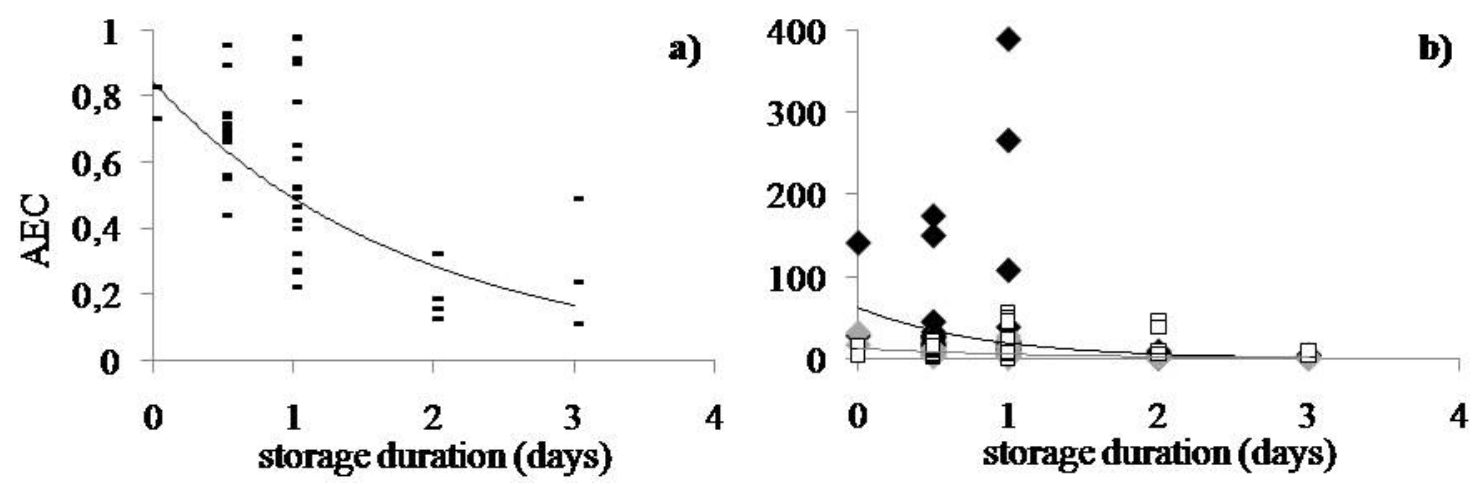

Fig. 3.

Fig. 3. (a) Adenylate Energy Charge (AEC, black dash) and (b) in nanomoles.10 ${ }^{-9}$ spermatozoa, Adenosine triphosphate content (ATP, black diamond's), Adenosine diphosphate content (ADP, grey diamond's) and Adenosine monophosphate content (AMP, empty squares) in nanomoles. $10^{-9}$ spermatozoa, as function of time of hake sperm storage at $4^{\circ} \mathrm{C}$ (in days). Regressions plots fitted to the respective data set (a): $A E C=0.842 \mathrm{e}^{-0.541 \mathrm{x}} ; \mathrm{R}^{2}=0.492$ and $(\mathrm{b})$ ATP $=628 \mathrm{e}^{-1.185 \mathrm{x}} ; \mathrm{R}^{2}=0.421 ; \quad A D P=127 \mathrm{e}^{-}$ $0.787 \times ; R^{2}=0.490$. 